\section{Physical Properties of Various Coconut Coir Dusts Compared to Peat}

\author{
Manuel Abad, ${ }^{1}$ Fernando Fornes, Carolina Carrión, and \\ Vicente Noguera \\ Instituto Agroforestal Mediterráneo, Universidad Politécnica de Valencia, \\ P.O. Box 22012, E46071 Valencia, Spain
}

Patricia Noguera, Ángel Maquieira, and Rosa Puchades

Departamento de Química, Universidad Politécnica de Valencia, P.O. Box 22012, E46071 Valencia, Spain

Additional index words. air-water relationships, relative hydraulic conductivity, coarseness index, particle size distribution, container media, Cocos nucifera, sphagnum peat

\begin{abstract}
Selected physical properties of 13 coconut coir dusts from Asia, America, and Africa were compared to physical properties of sphagnum peat. All properties studied differed significantly between and within sources, and from the peat. Coir dusts from India, Sri Lanka, and Thailand were composed mainly of pithy tissue, whereas most of those from Costa Rica, Ivory Coast, and Mexico contained abundant fiber which was reflected by a higher coarseness index (percentage by weight of particles larger than 1 $\mathrm{mm}$ in diameter). Coir dust was evaluated as a lightweight material, and its total porosity was above $94 \%$ (by volume). It also exhibited a high air content (from $24 \%$ to $89 \%$ by volume) but a low easily available and total water-holding capacity which ranged from $<1 \%$ to $36 \%$ by volume and from 137 to $786 \mathrm{~mL} \cdot \mathrm{L}^{-1}$, respectively. Physical properties of coir dust were strongly dependent on particle size distribution. Both easily available and total water-holding capacity declined proportionally with increasing coarseness index, while air content was positively correlated. Relative hydraulic conductivity in the range of 0 to $10 \mathrm{kPa}$ suction dropped as particle size increased. Coir dusts with a particle size distribution similar to peat showed comparatively higher aeration and lower capacity to hold total and easily available water. An air-water balance similar to that in peat became apparent in coir dust at a comparatively lower coarseness index $(29 \%$ vs. $63 \%$ by weight in peat). Stepwise multiple regression analysis showed that particles with diameters in the range of 0.125 to $1 \mathrm{~mm}$ had a remarkable and highly significant impact on the physical properties studied, while particles $<0.125 \mathrm{~mm}$ and $>1 \mathrm{~mm}$ had only a slight or nonsignificant effect.
\end{abstract}

Sphagnum peat is a widely used medium constituent for the production of containerized crops (Bunt, 1988; Puustjärvi, 1977; Raviv et al., 1986, 2002; Schmilewski, 1996), particularly in the U.S., Europe, and Canada. However, given the rising price of high-quality horticultural peat (Raviv et al., 1986), peat's highly conducive effects for diseases caused by a variety of soilborne plant pathogens (Cotxarrera et al., 2002), and its questionable future availability due to environmental constraints (Robertson, 1993), there has been a worldwide search for suitable alternatives to peat since the late 1970s (Morel et al., 2000; Pryce, 1991; Raviv et al., 1986).

With regard to this search, much attention has been paid to recycling and reclaiming solid organic wastes generated by production, industrial and consumer activities for use as soilless growing media ingredients for containerized crop production (Abad et al.,

Received for publication 20 May 2005. Accepted for publication 10 July 2005. The authors are grateful to Michael Raviv of the Newe Ya'ar Research Center, ARO, Ramat Yishay, Israel, and Silvia Burés from Burés S.A., Barcelona, Spain, for their critical reading of the manuscript. Thanks also to Debra Westall for revising the English.

${ }^{1}$ To whom reprint requests should be addressed; e-mailmabad@prv.upv.es. other countries in Asia, tropical America, and Africa are also major coconut producers and processors (FAO, 2003). Nevertheless, research into $\mathrm{CD}$ physical properties-which affect irrigation management-is scarce and incomplete, and most of these studies concentrate only on coirs from Sri Lanka (Meerow, 1994, 1995) or a few Asian countries (Evans et al., 1996; Handreck, 1992, 1993; Konduru et al., 1999; Stamps and Evans, 1997). Furthermore, contradictory reports have been published in the literature (Fornes et al., 2003) since it has been stated that in comparison with sphagnum peat $C D$ shows either a similar or superior ability to hold water (Cresswell, 1992; Evans et al., 1996; Handreck, 1992, 1993), or a lower water-holding capacity (Bragg, 1998; Noguera et al., 1997, 2000; Prasad, 1997), and reversely for the aeration properties. In addition, little work has been undertaken to examine the effect of particle size distribution on the physical properties of $\mathrm{CD}$ as container medium.

Therefore, an in-depth study of the physical properties - and their relationships - of various coir dusts from different tropical countries would considerably improve existing knowledge regarding the characteristics of this material as well as irrigation practices when using $\mathrm{CD}$ as a container medium component.

The objectives of this research were to determine the main physical properties of thirteen CD samples from different sources for use as peat substitutes, and to examine both their variability and the effect of particle size distribution on the properties studied.

\section{Materials and Methods}

$C D$ and peat samples. Thirteen $\mathrm{CD}$ samples from six countries in Africa, tropical America, and Asia and one peat sample from Canada were characterized and compared at the physical level.

The CD samples were either collected by one of the authors or provided by collaborators from Costa Rica (Cocos La Costa Ltda., San José; samples CR1 and CR2), India (Comptoir Roussillonnais, Madras; IN1), Ivory Coast (Tropical Plantation Fruit Co., Daloa; IC1), Mexico (Eco Productos Palmira, Colima; ME1 to ME4), Sri Lanka (Delmege Forsyth Co. Ltd., Colombo; SL1 and SL2), and Thailand (Chia Thai Seed Co. Ltd., Bangkok; TH1 to TH3). In each country, samples were labelled by increasing particle size (coarseness index, see below). Coir dusts were selected according to their different sources, processing methods, commercial presentations, relative proportions of pith to fiber, and colors. CD samples from Asian countries came from husks that were retted (soaked in water) during the coir extraction process, whereas the African and American ones came from unretted husks, processed by mechanical means only. Samples SL2, TH1, TH2, and TH3 were collected as highly compressed dried bricks $(0.8$ to $1.2 \mathrm{~L}$ volume, compression ratio $6: 1$ to $10: 1)$, IN1 and SL1 as compressed bales (5.8 to $13.0 \mathrm{~L}$, compression ratio about $4: 1$ ), and CR1, CR2, IC1, ME1, ME2, ME3, and ME4 as moist, loose materials. All the CD products were com- 
mercially produced and marketed as container media ingredients for soilless substrate culture. Four random samples (about $25 \mathrm{~L} /$ sample) were collected from each batch. Coir dusts were rehydrated with distilled water according to manufacturers' instructions before laboratory determinations. In addition, CD compressed samples were expanded mechanically to recover the original volume.

The peat sample used as standard material (control) for comparisons was a light and weakly decomposed (H1-H3 in accordance with the humification scale; Von Post, 1937) Canadian sphagnum peat (Annapolis Valley Peat Moss Co., Berwick, Nova Scotia). This purchased sample was representative of the peat commonly used for container grown crops. It was marketed in bales of compressed dried product and imported by Comercial Projar S.A. (Valencia, Spain). It was expanded mechanically and rehydrated with distilled water.

Physical characterization. Particle size distribution was determined on $200 \mathrm{~mL}$ airdried samples. Particle sizes were separated by means of an electromagnetic, digital vibratory shaker (model 002; CISA, Spain) for $10 \mathrm{~min}$ at the highest intensity, using sieves of $200 \mathrm{~mm}$ in diameter and square mesh sizes of $0.125,0.25$, $0.5,1,2,4,8$, and $16 \mathrm{~mm}$. Material collected in each sieve was weighed and expressed as percentage by weight of the whole sample. Both the geometric particle-size diameter $\left(\mathrm{d}_{\mathrm{g}}\right)$-the geometric mean diameter of particles-and the geometric particle-size standard deviation $\left(\sigma_{g}\right)$ - an indicator of the degree of the spread of the particle-size distribution curve-were calculated using the following expressions (Shirazi and Boersma, 1984): $\mathrm{d}_{\mathrm{g}}=\exp$ (a) and $\sigma_{\mathrm{g}}=\exp (\mathrm{b})$, where

$$
\mathrm{a}=\sum_{\mathrm{i}} \mathrm{m}_{\mathrm{i}} \ln \mathrm{d}_{\mathrm{i}} \quad \text { and } \quad \mathrm{b}=\sqrt{\sum_{\mathrm{i}} \mathrm{m}_{\mathrm{i}}\left(\ln \mathrm{d}_{\mathrm{i}}\right)^{2}-\mathrm{a}^{2}}
$$

with $m_{i}$ being the fraction of total CD mass having diameters equal to or less than the sieve $i$, and $d_{i}$ equal to the average (arithmetic mean) mesh diameter of two consecutive sieves. In addition, the coarseness index (CI) - a parameter that defines the particle size distribution with one single value - was calculated and expressed as the cumulative percentage by weight for all particles with a diameter larger than $1 \mathrm{~mm}$ (i.e., the sum of fractions with particle sizes ranging from $>1 \mathrm{~mm}$ to $>16 \mathrm{~mm}$ ) (adapted from Richards et al., 1986).

The water release curve of CD samples for a suction range of 0 to $10 \mathrm{kPa}$ (series of water suction applied $=1,2,3,5$, and $10 \mathrm{kPa}$ ) was determined according to De Boodt et al. (1974). These authors also defined the air-water relationships determined in the present work. Total pore space is the percentage of the volume of the material that can actually be filled with water. Air content is the difference-in percentage by volume-between the total pore space and the moisture content at a suction of $1 \mathrm{kPa}$. Easily available water is the percentage by volume of water released from the material when the suction increases from 1 to $5 \mathrm{kPa}$. Water buffering capacity is the volume-in percentage-of water released from the material when the suction increases from 5 to $10 \mathrm{kPa}$.
The retention characteristic model proposed by Van Genuchten (1980) was used to fit the measured water release curves and to describe the hydraulic properties of CD samples. This model is expressed by the following equation: $\theta(\mathrm{h})=\theta_{\mathrm{r}}+\left(\theta_{\mathrm{s}}-\theta_{\mathrm{r}}\right) /\left[1+(\alpha \mathrm{h})^{\mathrm{n}}\right]^{\mathrm{m}}$ where $\theta(\mathrm{h})$ is the volumetric moisture content at the water suction $(\mathrm{h}$ in $\mathrm{cm}$ ) applied when measuring the retention curve; $\theta_{\mathrm{r}}$ and $\theta_{\mathrm{s}}$ are the residual and the saturated water content, respectively; and $\alpha, \mathrm{n}$, and $\mathrm{m}$ are parameters that determine the shape of the curve. Both $\theta(\mathrm{h})$ and $\theta$ were measured $-\theta_{\mathrm{s}}$ by saturating the samples before the suction increase-whereas $\theta, \alpha, n$, and $m$ were estimated by fitting the measured retention curve to the model and assuming that $\mathrm{m}$ $=1-1 / \mathrm{n}$ (Van Genuchten and Nielsen, 1985). Moreover, the relative hydraulic conductivity- $\mathrm{K}_{\mathrm{r}}(\mathrm{h})$-of CD samples was predicted by combining the hydraulic models proposed by both Van Genuchten (1980) and Mualem (1976), using the equation:

$\frac{\mathrm{K}_{\mathrm{r}}(\mathrm{h})=\left[1-(\alpha \mathrm{h})^{\mathrm{n}-1}\left[1+(\alpha \mathrm{h})^{\mathrm{n}}\right]^{-\mathrm{m}}\right]^{2}}{\left[1+(\mathrm{ah})^{\mathrm{n}}\right]^{\mathrm{m} / 2}}$

where $h, \alpha, n$, and $m$ mean the same as that previously stated.

Bulk density and total water-holding capacity at container capacity were determined using loosely packed cores and methods adapted from De Boodt et al. (1974) and Evans et al. (1996). In the present study, steel cylinders measuring $40 \mathrm{~mm}$ in height and $82.3 \mathrm{~mm}$ internal diameter (about $210 \mathrm{~mL}$ ) were used.

Finally, wettability characteristics were determined according to AS 3743 (Australian Standard 3743) and the results expressed in minutes taken for the water to soak into the substrate. All physical determinations were replicated four times.

Data analysis. An analysis of variance (ANOVA) was conducted to determine if CD source significantly affected the physical properties studied and to compare the coirs tested with the sphagnum peat used as control. Where significant differences did exist, a Newman-Keuls multiple range test was conducted at $P \leq 0.05$ to establish significant differences between means. Linear regressions were fitted by least squares and determination coefficients $\left(r^{2}\right)$ were calculated. Stepwise multiple regression analysis was used to find a limited set of independent variables with which the dependent variable might be predicted adequately. All statistical analyses and correlations were performed using the Statgraphics Plus 4.1 statistical package (Statistical Graphics Corp., 1999).

\section{Results and Discussion}

Physical properties of $C D$ and their comparison with peat. The particle size distribution varied considerably between the different samples tested with the graphs fluctuating between flattened and spread distribution curves (Fig. 1). Further, data for $\sigma_{g}$ indicated that the coir from India (IN1) was the most homogeneous (well graded), whereas sample ME4 from Mexico was the most heterogeneous (poorly graded) (Table 1).
From the 9 sieved fractions with particle sizes ranging from $<0.125 \mathrm{~mm}$ to $>16 \mathrm{~mm}$ in diameter, the frequency of the most abundant particle-size ranges was: 0.5 to $1 \mathrm{~mm}, 8$ samples; 0.25 to $0.5 \mathrm{~mm}, 2$ samples; 1 to 2 $\mathrm{mm}, 2$ samples; 8 to $16 \mathrm{~mm}, 1$ sample (Fig. 1 ). In all the coir dusts from India, Sri Lanka, and Thailand as well as in some from Costa Rica (CR1) and Mexico (ME1 and ME2), most of the particles were from pithy tissue (particle diameter $<8 \mathrm{~mm}$, according to Evans et al., 1996). Sample TH1 from Thailand had the greatest amount of fine particles $(<0.5 \mathrm{~mm})$ and hence the smallest $d$ (Table 1). On the contrary, most of the samples from Costa Rica, Ivory Coast and Mexico contained abundant fiber (particle diameter $>8 \mathrm{~mm}$, according to Evans et al., 1996) and therefore showed the largest $d_{g}$. The CI, expressed as the cumulative percentage by weight of particles larger than 1 $\mathrm{mm}$, ranged from $12 \%$ to $66 \%$, the lowest value being for sample TH1 and the highest for ME4 (Table 1). Differences in particle size distribution observed between CD sources are probably related to the most complete extraction and exploitation of the long coir fibers when processing the raw coconut husks in Asian countries as compared to those husks processed in African and American locations (Fornes et al., 2003). When comparing coir dusts taken from the same country, both the CI and the $\mathrm{d}_{\mathrm{g}}$ fluctuated widely and significantly between the different samples collected with the exception of Sri Lanka, where particle size did not differ between the two coirs tested (Table 1). This could be because this country has become the leading processor of $\mathrm{CD}$ as horticultural substrate (Handreck, 1993; Konduru et al., 1999; Meerow, 1994), and the manufacturers apply severe quality control standards. Moreover, CD particle size was generally smaller than that of peat (Table 1).

CD was evaluated as a lightweight material with bulk density varying from $<0.03 \mathrm{~g} \cdot \mathrm{cm}^{-3}$ to about $0.09 \mathrm{~g} \cdot \mathrm{cm}^{-3}$ (Table 2). For each CD source, bulk density decreased when the CI increased. Bulk density of peat was in general significantly higher than that of $\mathrm{CD}$.

Good and highly significant agreement between the measured and the fitted water retention data - following the model proposed by Van Genuchten (1980) - was obtained throughout the tested suction range (0 to 10 $\mathrm{kPa}$ ) for the $\mathrm{CD}$ samples examined in this study $\left(R^{2} \geq 0.985\right.$ in all the cases, $\left.P \leq 0.001\right)$ (data not shown).

CD showed a particularly high total porosity for air and water, the total pore space reaching levels as high as $98.3 \%$ of the volume (Table 2 ). Total pore space and bulk density were closely and inversely related. From the values of these parameters for the thirteen coir dusts studied, the following relationship was established: TPS $=99.9-64.8 \mathrm{BD}\left(r^{2}=0.988, P \leq 0.001\right)$ in which TPS is the total pore space ( $\%$ by volume) and BD represents the bulk density $\left(\mathrm{g} \cdot \mathrm{cm}^{-3}\right)$. Furthermore, for the coirs from the same country, total porosity increased with increasing CI.

Given the remarkable differences in particle size distribution between $\mathrm{CD}$ samples, the 

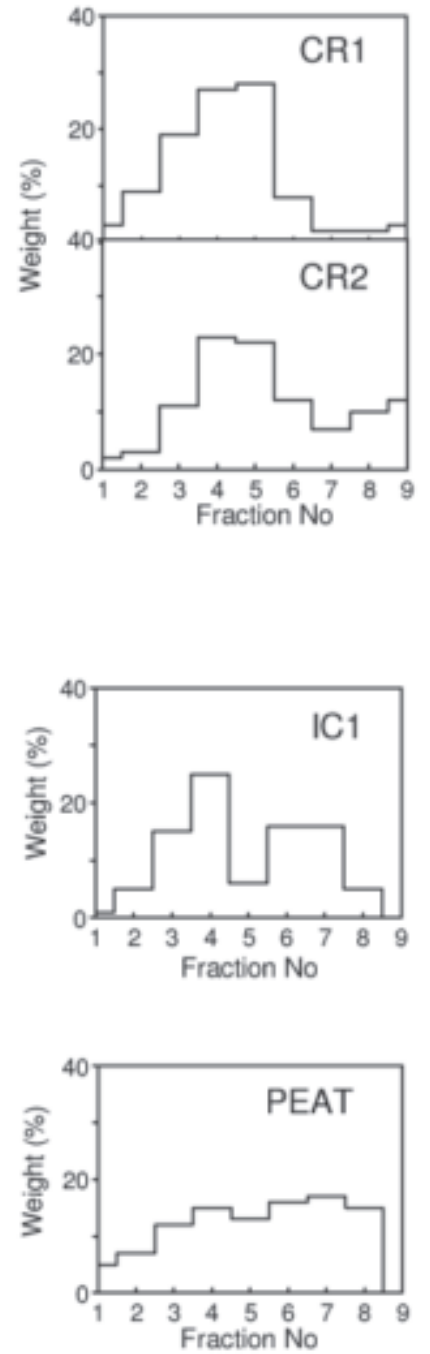

Fig. 1. Particle size distribution of thirteen coir dusts from different sources, and of the sphagnum peat (PEAT). $\mathrm{CR}=$ Costa Rica; IC = Ivory Coast; IN $=$ India; $\mathrm{ME}=$ Mexico; $\mathrm{SL}=$ Sri Lanka; $\mathrm{TH}=$ Thailand. In each country, samples were labelled by increasing coarseness index.

air-water relationships also varied sharply and significantly (Table 2 ). Air content ranged from $24.2 \%$ for $\mathrm{TH} 1$ to $89.4 \%$ of the volume for ME4, whereas the easily available water varied between $36.0 \%$ and $<1 \%$ of the volume for samples TH1 and ME4, respectively. Water buffering capacity averaged $3.5 \%$ by volume, the lowest limit corresponding to ME4 (0.2\%) and the highest to TH2 (7.5\%). Total waterholding capacity fluctuated between 137 and $786 \mathrm{~mL}$ water/L substrate for samples ME4 and $\mathrm{TH} 1$, respectively. The remarkably small values for both easily available water and water buffering capacity in some of the coir dusts studied, especially in samples ME4, ME3, $\mathrm{CR} 2$, and $\mathrm{IC} 1$, are not related to the actual availability of water to plant roots growing in these substrates (Fornes et al., 2003; Hüttermann et al., 1999). Laboratory methods (De Boodt et al., 1974) underestimate these parameters for coarse-textured substrates relative to the water volume that plants take up from the medium. That occurs because of the loss of contact between water and particles as
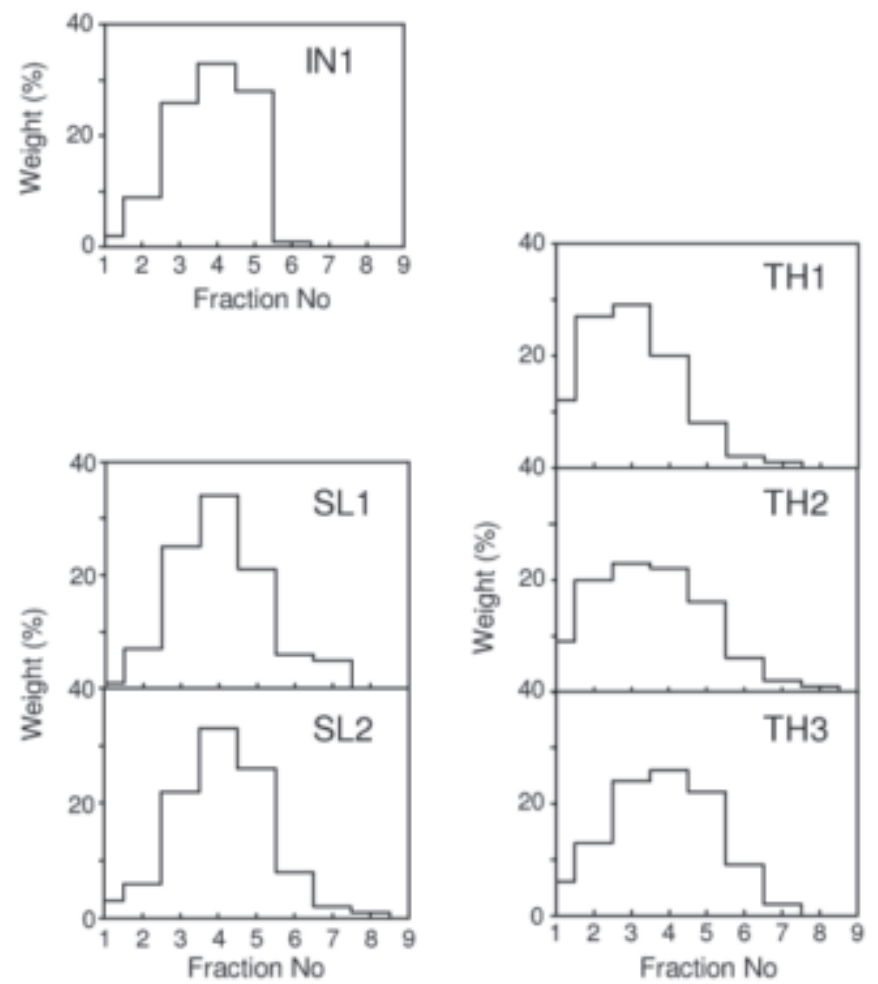

\begin{tabular}{|cl|cl|}
\hline Fraction No & \multicolumn{1}{c|}{$\mathrm{mm}$} & \multicolumn{2}{c|}{ Fraction No $\mathrm{mm}$} \\
\hline 1 & $<0.125$ & 6 & $2-4$ \\
2 & $0.125-0.25$ & 7 & $4-8$ \\
3 & $0.25-0.5$ & 8 & $8-16$ \\
4 & $0.5-1$ & 9 & $>16$ \\
5 & $1-2$ & & \\
\hline
\end{tabular}

Table 1. Geometric particle-size diameter $\left(\mathrm{d}_{\mathrm{g}}\right)$, geometric particle-size standard deviation $\left(\sigma_{\mathrm{g}}\right)$, and coarseness index $(\mathrm{CI})$ of coir dusts from different sources. Comparison with peat. Each value is the mean of four replications.

\begin{tabular}{|c|c|c|c|}
\hline Source & $\begin{array}{c}\mathrm{d}_{\mathrm{g}} \\
(\mathrm{mm})\end{array}$ & $\sigma_{g}$ & $\begin{array}{c}\mathrm{CI} \\
(\% \text { by wt) }\end{array}$ \\
\hline \multicolumn{4}{|c|}{ Costa Rica (CR) } \\
\hline CR1 & $0.89 \mathrm{a}^{\mathrm{z}}$ & $3.14 \mathrm{~cd}$ & $43 \mathrm{f}$ \\
\hline CR2 & $2.01 \mathrm{c}$ & $4.28 \mathrm{e}$ & $62 \mathrm{~h}$ \\
\hline \multicolumn{4}{|c|}{ Ivory Coast (IC) } \\
\hline $\mathrm{IC} 1$ & $1.38 \mathrm{~b}$ & $3.16 \mathrm{~cd}$ & $53 \mathrm{~g}$ \\
\hline \multicolumn{4}{|l|}{ India (IN) } \\
\hline IN1 & $0.65 \mathrm{a}$ & $2.11 \mathrm{a}$ & $29 \mathrm{~cd}$ \\
\hline \multicolumn{4}{|l|}{ Mexico (ME) } \\
\hline ME1 & $0.57 \mathrm{a}$ & $2.53 \mathrm{abc}$ & $22 \mathrm{~b}$ \\
\hline ME2 & $0.75 \mathrm{a}$ & $3.29 \mathrm{~d}$ & $35 \mathrm{de}$ \\
\hline ME3 & $1.57 \mathrm{~b}$ & $3.87 \mathrm{e}$ & $62 \mathrm{~h}$ \\
\hline ME4 & $2.34 \mathrm{~d}$ & $5.05 \mathrm{f}$ & $66 \mathrm{~h}$ \\
\hline \multicolumn{4}{|c|}{ Sri Lanka (SL) } \\
\hline SL1 & $0.78 \mathrm{a}$ & $2.37 \mathrm{ab}$ & $31 \mathrm{de}$ \\
\hline SL2 & $0.79 \mathrm{a}$ & $2.51 \mathrm{abc}$ & $36 \mathrm{e}$ \\
\hline \multicolumn{4}{|c|}{ Thailand (TH) } \\
\hline TH1 & $0.35 \mathrm{a}$ & $2.63 \mathrm{abcd}$ & $12 \mathrm{a}$ \\
\hline $\mathrm{TH} 2$ & $0.51 \mathrm{a}$ & $3.06 \mathrm{~cd}$ & $25 \mathrm{bc}$ \\
\hline TH3 & $0.62 \mathrm{a}$ & $2.81 \mathrm{abcd}$ & $33 \mathrm{de}$ \\
\hline Peat & $1.73 \mathrm{bc}$ & $4.30 \mathrm{e}$ & $63 \mathrm{~h}$ \\
\hline Significance & $* * *$ & $* * *$ & $* * *$ \\
\hline
\end{tabular}

zMean separation within columns by Newman-Keuls multiple range test at $P \leq 0.05$.

${ }^{* * *}$ Significant at $P \leq 0.001$.

the initial water is removed by bottom suction. This condition produces artificially low values for those parameters despite the high air content of these materials. Under these conditions, the unsaturated hydraulic conductivity-being a characteristic function of the medium and 
Table 2. Selected physical properties of coir dusts from different sources and their comparison with peat. Each value is the mean of four replications.

\begin{tabular}{|c|c|c|c|c|c|c|}
\hline Source & $\begin{array}{c}\text { Bulk } \\
\text { density } \\
\left(\mathrm{g} \cdot \mathrm{cm}^{-3}\right)\end{array}$ & $\begin{array}{c}\text { Total } \\
\text { pore } \\
\text { space } \\
(\% \text { by vol })\end{array}$ & $\begin{array}{c}\text { Air } \\
\text { content } \\
(\% \text { by vol) }\end{array}$ & $\begin{array}{c}\text { Easily } \\
\text { available } \\
\text { water } \\
(\% \text { by vol) }\end{array}$ & $\begin{array}{c}\text { Water } \\
\text { buffering } \\
\text { capacity } \\
\text { (\% by vol) }\end{array}$ & $\begin{array}{c}\text { Total } \\
\text { water- } \\
\text { holding } \\
\text { capacity } \\
\left(\mathrm{mL} \cdot \mathrm{L}^{-1}\right)\end{array}$ \\
\hline \multicolumn{7}{|c|}{ Costa Rica (CR) } \\
\hline CR1 & $0.041 \mathrm{~b}^{\mathrm{z}}$ & $97.0 \mathrm{~d}$ & $59.6 \mathrm{e}$ & $14.4 \mathrm{~d}$ & $2.9 \mathrm{~b}$ & $417 \mathrm{~d}$ \\
\hline CR2 & $0.026 \mathrm{a}$ & $98.2 \mathrm{e}$ & $75.3 \mathrm{~g}$ & $4.9 \mathrm{~b}$ & $1.3 \mathrm{a}$ & $252 \mathrm{~b}$ \\
\hline \multicolumn{7}{|c|}{ Ivory Coast (IC) } \\
\hline \multicolumn{6}{|l|}{ India (IN) } & $276 \mathrm{c}$ \\
\hline IN1 & $0.056 \mathrm{c}$ & $96.3 \mathrm{c}$ & $41.2 \mathrm{~cd}$ & $21.6 \mathrm{f}$ & $6.5 \mathrm{de}$ & $547 \mathrm{e}$ \\
\hline \multicolumn{7}{|c|}{ Mexico (ME) } \\
\hline ME1 & $0.072 \mathrm{e}$ & $95.2 \mathrm{~b}$ & $43.7 \mathrm{~d}$ & $22.8 \mathrm{f}$ & $5.2 \mathrm{~cd}$ & $639 \mathrm{f}$ \\
\hline ME2 & $0.061 \mathrm{~cd}$ & $95.9 \mathrm{bc}$ & $57.8 \mathrm{e}$ & $14.7 \mathrm{~d}$ & $3.0 \mathrm{~b}$ & $458 \mathrm{~d}$ \\
\hline ME3 & $0.039 \mathrm{~b}$ & $97.4 \mathrm{~d}$ & $83.3 \mathrm{~h}$ & $2.6 \mathrm{ab}$ & $0.3 \mathrm{a}$ & $201 \mathrm{~b}$ \\
\hline ME4 & $0.025 \mathrm{a}$ & $98.3 \mathrm{e}$ & $89.4 \mathrm{i}$ & $0.7 \mathrm{a}$ & $0.2 \mathrm{a}$ & $137 \mathrm{a}$ \\
\hline \multicolumn{7}{|c|}{ Sri Lanka (SL) } \\
\hline SL1 & $0.089 \mathrm{f}$ & $94.1 \mathrm{a}$ & $31.7 \mathrm{~b}$ & $22.5 \mathrm{f}$ & $5.3 \mathrm{~cd}$ & 585 ef \\
\hline SL2 & $0.072 \mathrm{e}$ & $95.1 \mathrm{~b}$ & $42.0 \mathrm{~cd}$ & $22.4 \mathrm{f}$ & $4.0 \mathrm{bc}$ & $541 \mathrm{e}$ \\
\hline \multicolumn{7}{|c|}{ Thailand (TH) } \\
\hline TH1 & $0.073 \mathrm{e}$ & $95.2 \mathrm{~b}$ & $24.2 \mathrm{a}$ & $36.0 \mathrm{~h}$ & $4.8 \mathrm{c}$ & $786 \mathrm{~g}$ \\
\hline TH2 & $0.063 \mathrm{~cd}$ & $95.8 \mathrm{bc}$ & $37.3 \mathrm{c}$ & $27.7 \mathrm{~g}$ & $7.5 \mathrm{e}$ & $648 \mathrm{f}$ \\
\hline TH3 & $0.056 \mathrm{c}$ & $96.2 \mathrm{c}$ & $45.3 \mathrm{~d}$ & $18.6 \mathrm{e}$ & $3.0 \mathrm{~b}$ & $533 \mathrm{e}$ \\
\hline Peat & $0.084 \mathrm{f}$ & $94.2 \mathrm{a}$ & $41.2 \mathrm{~cd}$ & $22.5 \mathrm{f}$ & $4.4 \mathrm{bc}$ & $620 \mathrm{f}$ \\
\hline Significance & $* * *$ & $* * *$ & $* * *$ & $* * *$ & $* * *$ & $* * *$ \\
\hline
\end{tabular}

${ }^{2}$ Mean separation within columns by Newman-Keuls multiple range test at $P \leq 0.05$.

*** Significant at $P \leq 0.001$.

highly sensitive to moisture variation - is a better indicator of the actual availability of water to the roots (Raviv et al., 1999; Wallach et

al., 1992a, 1992b). Moreover, the hydrophobic characteristics of these four samples, particularly ME4, could be partly responsible for their
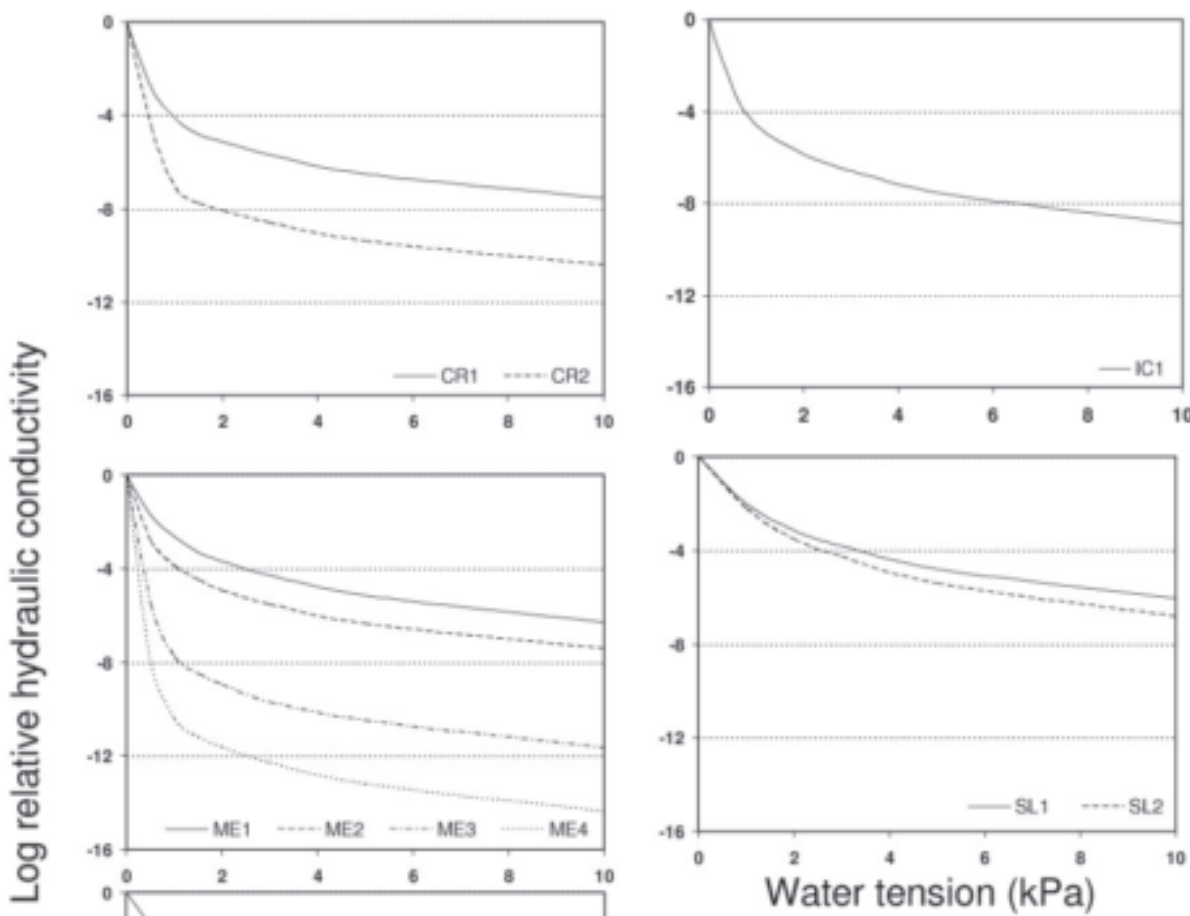

poor water-holding properties. The hydraulic characteristics of the coir dusts tested were also studied since the hydraulic conductivity indicates the actual availability of water to plant roots better than the static approach to easily available water, and therefore it should be used for effective management of irrigation and fertilization in soilless substrate culture (Raviv etal., 1999, 2002; Wallach et al., 1992a, 1992b). In the present study a first approximation towards the estimation of hydraulic conductivity was attempted by predicting the relative hydraulic conductivity, $\mathrm{K}_{\mathrm{r}}(\mathrm{h})$. The predicted relative hydraulic conductivity vs. suction for the thirteen CD samples is shown in Fig. 2. As suction increased from 0 to $1 \mathrm{kPa}$, $\mathrm{K}$ (h) decreased significantly from about two orders of magnitude for TH1 to eleven orders of magnitude for ME4. The predicted values of $\mathrm{K}_{\mathrm{r}}(\mathrm{h})$ also declined as suction increased from 1 to $5 \mathrm{kPa}$ (over the range of easily available water), but were horizontally asymptotic at higher tensions (from 5 to $10 \mathrm{kPa}$, over the water buffering capacity range). The hydraulic characteristics of CD clustered around those of peat with significant differences between them, and were in ranges similar to those found for other materials used as container media (Raviv et al., 1999; Wallach et al., 1992a, 1992b).

Finally, the wettability results obtained indicated that $\mathrm{CD}$ is a material which rehydrates easily and rapidly. In general, wettability data
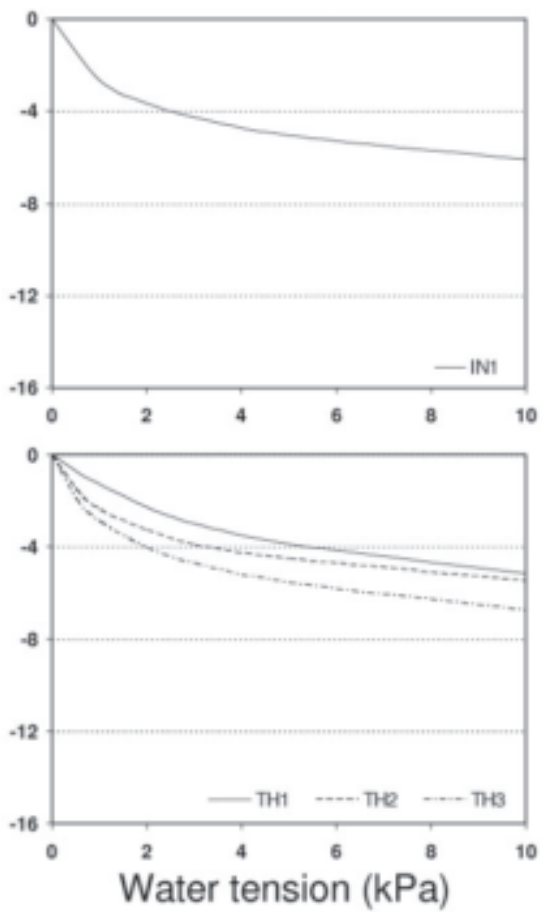

Fig. 2. Predicted relative hydraulic conductivity vs. water tension of thirteen coir dusts from different sources, and that of peat (PEAT). $\mathrm{CR}=$ Costa Rica; IC = Ivory Coast; IN = India; $\mathrm{ME}=$ Mexico; $\mathrm{SL}=$ Sri Lanka; $\mathrm{TH}=$ Thailand. In each country, samples were labelled by increasing coarseness index. 


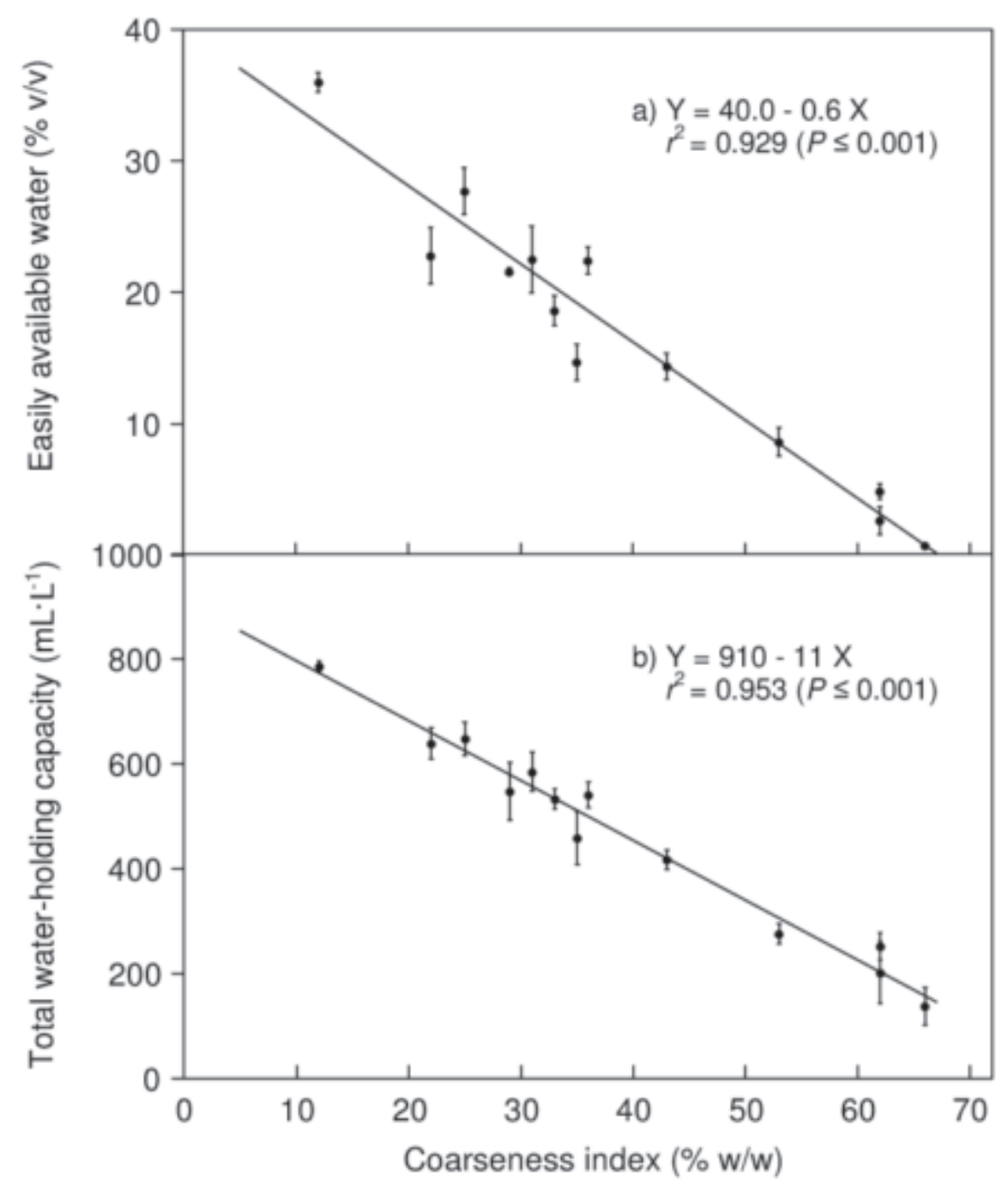

for $\mathrm{CD}$ were under $7 \mathrm{~min}$, a value much lower than that for peat (19 min) (data not shown).

Particle size distribution effect on physical properties of $C D$. Physical properties of container media depend on the material used, the particle size distribution, and the packing characteristics of particles (Burés et al., 1993a, 1993b). Moreover, particle size affects pore size distribution and, hence, the air-water balance in the medium (Evans et al., 1996; Raviv et al., 1986, 2002).

At this stage of the research, it was con-

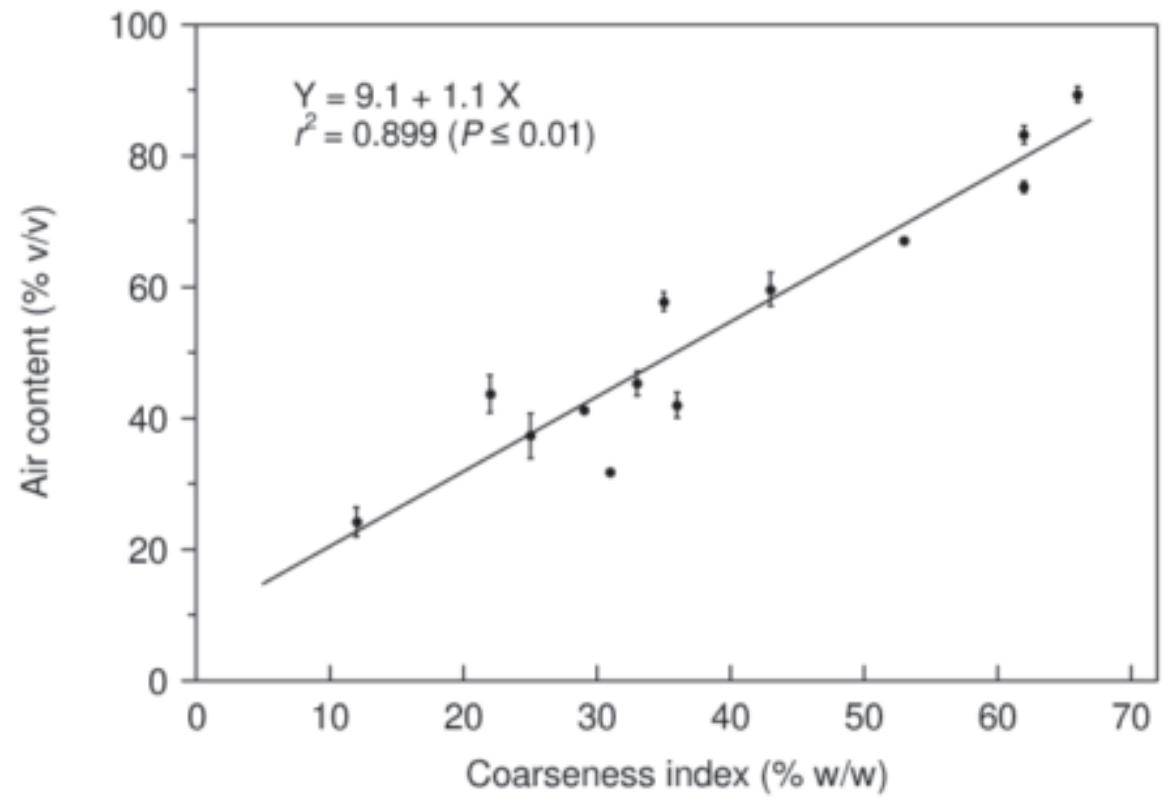

Fig. 3. Relationship between the water-holding properties of thirteen coir dusts from different sources and their particle size distribution expressed as the coarseness index (percentage by weight of particles with $\varnothing>1 \mathrm{~mm}$ ). (a) Easily available water, (b) total water-holding capacity. Each value is the mean of four replications \pm the standard error of the mean.

sidered valuable to study the results for CD physical properties by regression analysis using the CI. By regression of the experimental data, linear models were established with optimum fittings (coefficient of determination, $r^{2}$, highly significant) (Figs. 3 and 4). Both total waterholding capacity and easily available water declined proportionally with increasing CI. On the contrary, air content was positively correlated to the CI.

To achieve optimal plant growth, a high content of easily available water (20\% to $30 \%$ by volume) together with an adequate air supply ( $20 \%$ to $30 \%$ by volume) are considered to be the most important physical characteristics of container media (Bunt, 1988; Fonteno and Bilderback, 1983; Raviv et al., 2002; Richards et al., 1986; Rivière et al., 1990). CD complied with these conditions when the CI was around 20\% (Figs. 3 and 4 ).

CD samples with a CI similar to sphagnum peat showed comparatively higher aeration and lower capacity to hold total and easily available water (Tables 1 and 2). An air-water balance similar to that in peat was registered in $\mathrm{CD}$ at a comparatively lower CI $(29 \%$ vs. $63 \%$ in peat) (Figs. 3 and 4). Differences in physical properties between peat and CD samples with similar particle size distribution are related to their microstructure and porosity characteristics. Pithy tissue particles in CD have been found (Fornes et al., 2003) to be highly porous (sponge-like), these particles exhibiting round external pores of around $44.3 \mu \mathrm{m}$ in diameter which accounted for a relative surface porosity of $40.9 \%$. By contrast, the cells of sphagnum moss leaves showed oval-shaped pores of 20.1 $\times 11.5 \mu \mathrm{m}$ and a relative surface porosity of only $12.0 \%$. Both significantly higher surface porosity and larger openings in pithy tissue particles of $\mathrm{CD}$ facilitate water penetration into the cells as well as subsequent drainage to a greater extent than in peat. This could explain the higher air content and the lower total and available water-holding capacity of $\mathrm{CD}$ in comparison to peat. Additionally, the larger pores of CD would allow the removal of water at lower suctions than with peat.

To determine which particle sizes $\left(\mathrm{X}_{\mathrm{n}}\right)$ control the main physical properties of $\mathrm{CD}$, experimental data for air content (AC, \% by volume), easily available water (EAW, \% by volume), and total water-holding capacity (TWHC, $\mathrm{mL} \cdot \mathrm{L}^{-1}$ ) were subjected to a regression analysis according to the stepwise variable

Fig. 4. Relationship between the aeration properties of thirteen coir dusts from different sources and their particle size distribution expressed as the coarseness index (percentage by weight of particles with $\varnothing>1 \mathrm{~mm}$ ). Each value is the mean of four replications \pm the standard error of the mean. 
selection procedure (property vs. particle size ranges). The following models were selected for these physical properties, taking into account the hypothesized signs for the regression coefficients and the highest coefficients of determination:

$\mathrm{AC}=123.3-3.3 \mathrm{X}_{1}\left(R^{2}=0.943 ; P \leq 0.001\right)$

$\mathrm{EAW}=-14.2+1.3 \mathrm{X}_{1}+0.4 \mathrm{X}_{2}\left(R^{2}=0.943\right.$; $P \leq 0.001)$

$\mathrm{TWHC}=-268+25 \mathrm{X}_{2}+18 \mathrm{X}_{3}\left(R^{2}=0.974\right.$; $P \leq 0.001)$

where $\mathrm{X}_{1}=$ Percentage of particles (by weight) within the size range 0.25 to $0.5 \mathrm{~mm}, \mathrm{X}_{2}=$ Percentage by weight of particles with diameters in the range of 0.125 to $0.25 \mathrm{~mm}$, and $\mathrm{X}_{3}=$ Percentage of particles (w/w) measuring between 0.5 and $1 \mathrm{~mm}$ in diameter. From these equations, it can be concluded that particles in the 0.125 to $1 \mathrm{~mm}$ size range had a remarkable and highly significant impact on the physical properties of $\mathrm{CD}$, while particles $<0.125 \mathrm{~mm}$ and $>1 \mathrm{~mm}$ had only a slight or nonsignificant effect. In addition, particles between 0.125 and $0.5 \mathrm{~mm}$ in diameter affected air content, easily available water, and total water-holding capacity to a significantly greater extent than did those in the 0.5 to $1 \mathrm{~mm}$ fraction.

The hydraulic characteristics of CD also depended on the particle size distribution (Fig. 2). Coarse-textured samples underwent a remarkable drop in relative hydraulic conductivity with the increase in the suction applied, whereas in the fine-textured coirs this physical parameter declined gradually. CD hydraulic conductivity was strongly correlated with the particle size distribution: $\mathrm{K}_{\mathrm{r}}(1 \mathrm{kPa})$ $=-2 \times 10^{-6} \mathrm{CI}^{3}+2 \times 10^{-4} \mathrm{CI}^{2}-9.4 \times 10^{-3} \mathrm{CI}$ $+0.1320\left(R^{2}=0.877 ; P \leq 0.001\right)$, where $\mathrm{K}_{\mathrm{r}}(1$ $\mathrm{kPa})$ is the relative hydraulic conductivity at 1 $\mathrm{kPa}$ suction, and $\mathrm{CI}$ stands for the coarseness index (in $\% \mathrm{w} / \mathrm{w}$ ).

Wide variations observed in particle size distribution and in physical properties between $\mathrm{CD}$ sources are probably related to two major factors: the coconut fruit itself, and the processing of the coconut husk (Evans et al., 1996; Fornes et al., 2003; Konduru et al., 1999; Noguera et al., 2000). Raw coconut fruits may vary in their proportions of pith to fiber in the mesocarp tissue, and hence in their particle size distribution. On the other hand, the degree of both husk grinding and screening of the remaining waste-grade coir may influence the relative proportions of particle sizes in the commercial product. Further, the age of the stockpiled CD could also affect its physical properties since long-term microbial degradation of organic materials leads to a significant reduction in the size of their constituent particles (Abad and Puchades, 2002; Orquín et al., 2001).

\section{Conclusions}

Physical properties of $\mathrm{CD}$ such as water supply and availability, aeration, and relative hydraulic conductivity strongly depend on particle size distribution. From the regression equations presented in this study, a CD-based medium with suitable physical characteristics for a specific soilless substrate culture system could be prepared by mixing adequate proportions of the different particle size fractions. By varying either the degree of husk grinding, the screen size or the screening strength of the waste-grade coir, or by selecting the $\mathrm{CD}$ age, coir dusts with specific particle size distributions could be obtained, and thus the required physical properties achieved. An understanding of how these factors affect the physical properties of CD is needed so that a consistent product with acceptable characteristics can be produced.

In addition, $\mathrm{CD}$ and peat differed remarkably in their particle size, and therefore, in their physical properties. As a consequence, irrigation schedules may need to be adjusted on a crop-by-crop basis.

Results obtained from this study will contribute to existing knowledge regarding the physical characteristics of CD, thus helping to improve irrigation management in $\mathrm{CD}$ container media.

\section{Literature Cited}

Abad, M. and R. Puchades. 2002. Compostaje de residuos orgánicos generados en la Hoya de Buñol (Valencia) con fines hortícolas [Composting of organic wastes produced in Hoya de Buñol (Valencia) for horticultural purposes]. Asociación para la Promoción Socio-económica Interior Hoya de Buñol, Valencia, Spain.

Abad, M., P. Noguera, and V. Noguera. 1997. Crecimiento de plantas ornamentales de hoja en sustratos de cultivo a base de fibra de coco (Growth of foliage ornamentals in coir dust-based substrates). Actas Hort. 17:76-81.

Abad, M., P. Noguera, and S. Burés. 2001. National inventory of organic wastes for use as growing media for ornamental potted plant production: case study in Spain. Bioresour. Technol. 77:197-200.

AS 3743 (Australian Standard 3743). 1993. Australian standard for potting mixes. 2nd ed. Stnd. Austral., Stnd. Assn. Austral., Homebush, NSW.

Bragg, N. 1998. Growing media. Nexus Media, Kent.

Bunt, A.C. 1988. Media and mixes for containergrown plants. 2nd ed. Unwin Hyman, London.

Burés, S., F.A. Pokorny, D.P. Landau, and A.M. Ferrenberg. 1993a. Computer simulation of volume shrinkage after mixing container media components. J. Amer. Soc. Hort. Sci. 118:757-761.

Burés, S., D.P. Landau, A.M. Ferrenberg, and F.A. Pokorny. 1993b. Monte Carlo computer simulation in horticulture: a model for container media characterization. HortScience 28:1074-1078.

Cotxarrera, L., M.I. Trillas-Gay, C. Steinberg, and C. Alabouvette. 2002. Use of sewage sludge compost and Trichoderma asperellum isolates to suppress Fusarium wilt of tomato. Soil Biol. Biochem. 34:467-476.

Cresswell, G.C. 1992. Coir dust - a viable alternative to peat? Proc. Austral. Potting Mix Manufacturers' Conf. 1:1-5.

De Boodt, M., O. Verdonck, and I. Cappaert. 1974. Method for measuring the water release curve of organic substrates. Acta Hort. 37:2054-2062.

Evans, M.R. and R.H. Stamps. 1996. Growth of bedding plants in sphagnum peat- and coir dust-based substrates. J. Environ. Hort. 14:187-190.

Evans, M.R., S. Konduru, and R.H. Stamps. 1996. Source variation in physical and chemical properties of coconut coir dust. HortScience 31:965-967.

FAO. 2003. Production yearbook 2002. vol. 56. FAO Stat. Ser. 176. FAO, Rome.

Fitzpatrick, G.E., E.R. Duke, and K.A. Klock-Moore.
1998. Use of compost products for ornamental crop production: research and grower experiences. HortScience 33:941-944.

Fonteno, W.C. and T.E. Bilderback. 1983. Physical property changes in three container media induced by a moisture extender. HortScience 18:570-574.

Fornes, F., R.M. Belda, M. Abad, P. Noguera, R. Puchades, A. Maquieira, and V. Noguera. 2003. The microstructure of coconut coir dusts for use as alternatives to peat in soilless growing media. Austral. J. Expt. Agr. 43:1171-1179.

Grimwood, B.E. 1977. Los productos del cocotero: su elaboración en los países en desarrollo [Coconut palm products: their manufacture in developing countries]. Estudios FAO de Producción y Protección Vegetal No. 7. FAO, Rome.

Handreck, K.A. 1992. The use of coir in potting media. Austral. Hort. (November):54-59.

Handreck, K.A. 1993. Properties of coir dust, and its use in the formulation of soilless potting media. Commun. Soil Sci. Plant Anal. 24:349-363.

Hüttermann, A., M.Zommorodi, and K. Reise. 1999. Addition of hydrogels to soil for prolonging the survival of Pinus halepensis seedlings subjected to drought. Soil Tillage Res. 50:295-304.

Konduru, S., M.R. Evans, and R.H. Stamps. 1999. Coconut husk and processing effects on chemical and physical properties of coconut coir dust. HortScience 34:88-90.

Mak, A.T.Y. and D.M. Yeh. 2001. Nitrogen nutrition of Spathiphyllum 'Sensation' grown in sphagnum peat- and coir-based media with two irrigation methods. HortScience 36:645-649.

Meerow, A.W. 1994. Growth of two subtropical ornamentals using coir dust (coconut mesocarp pith) as a peat substitute. HortScience 29:1984-1986.

Meerow, A.W. 1995. Growth of two tropical foliage plants using coir dust as a container media amendment. HortTechnology 5:237-239.

Meerow, A.W. 1997. Coir dust, a viable alternative to peat moss. Greenhouse Prod. News (Jan.):17-21.

Morel, P., L. Poncet, and L.M. Rivière. 2000. Les supports de culture horticoles. Institut National de la Recherche Agronomique (INRA), Paris.

Mualem, Y. 1976. A new model for predicting the hydraulic conductivity of unsaturated porous media. Water Resour. Res. 12:513-522.

Noguera, P., M. Abad, R. Puchades, V. Noguera, A. Maquieira, and J. Martínez. 1997. Physical and chemical properties of coir waste and their relation to plant growth. Acta Hort. 450:365-373.

Noguera, P., M. Abad, V. Noguera, R. Puchades, and A. Maquieira. 2000. Coconut coir waste, a new and viable ecologically-friendly peat substitute. Acta Hort. 517:279-286.

Offord, C.A., S. Muir, and J.L. Tyler. 1998. Growth of selected Australian plants in soilless media using coir as a substitute for peat. Austral. J. Expt. Agr. 38:879-887.

Orquín, R., M. Abad, P. Noguera, R. Puchades, V. Noguera, A. Maquieira, and P. de la Iglesia. 2001. Composting of Mediterranean seagrass and seaweed residues with yard waste for horticultural purposes. Acta Hort. 549:29-35.

Prasad, M. 1997. Physical, chemical and biological properties of coir dust. Acta Hort. 450:21-29.

Pryce, S. 1991. The peat alternatives manual. Friends of the Earth, London.

Puustjärvi, V. 1977. Peat and its use in horticulture. Liikekirjapaino Oy, Helsinki.

Raviv, M. 1998. Horticultural uses of composted material. Acta Hort. 469:225-234.

Raviv, M., Y. Chen, and Y. Inbar. 1986. Peat and peat substitutes as growth media for container-grown plants, p. 257-287. In: Y. Chen and Y.Avnimelech (eds.). The role of organic matter in modern 
agriculture. Martinus Nijhoff, Dordrecht.

Raviv, M., R. Wallach, A. Silber, S. Medina, and A. Krasnovsky. 1999. The effect of hydraulic characteristics of volcanic materials on yield of roses grown in soilless culture. J. Amer. Soc. Hort. Sci. 124:205-209.

Raviv, M., R. Wallach, A. Silber, and A. Bar-Tal. 2002. Substrates and their analysis, p. 25-101. In: D. Savvas and H. Passam (eds.). Hydroponic production of vegetables and ornamentals. Embryo Publ., Athens.

Richards, D., M. Lane, and D.V. Beardsell. 1986. The influence of particle-size distribution in pinebark:sand:brown coal potting mixes on water supply, aeration and plant growth. Scientia Hort. 29:1-14.

Rivière, L.M., J.C. Foucard, and F. Lemaire. 1990. Irrigation of crops according to the substrate. Scientia Hort. 43:339-349.

Robertson, R.A. 1993. Peat, horticulture and the environment. Biodiv. Conserv. 2:541-547.

Schmilewski, G.K. 1996. Horticultural use of peat, p. 327-334. In:E. Lappalainen(ed.). Global peat resources. Intl. Peat Soc., Jyskä, Finland.

Shirazi, M.A. and L. Boersma. 1984. A unifying quantitative analysis of soil texture. Soil Sci. Soc. Amer. J. 48:142-147.

Stamps, R.H. and M.R. Evans. 1997. Growth of Dieffenbachia maculata 'Camille' in growing media containing sphagnum peat or coconut coir dust. HortScience 32:844-847.

Stamps, R.H. and M.R. Evans. 1999. Growth of Dracaena marginata and Spathiphyllum 'Petite' in sphagnum peat- and coconut coir dust-based growing media. J. Environ. Hort. 17:49-52.

Statistical Graphics Corp. 1999. Statgraphics Plus for Windows 4.1. Stat. Graphics, Rockville, Md.

Van Genuchten, M.T. 1980. A closed-form equation for predicting the hydraulic conductivity of unsaturated soils. Soil Sci. Soc. Amer. J. 44:892-898.
Van Genuchten, M.T. and D.R. Nielsen. 1985. On describing and predicting the hydraulic properties of unsaturated soils. Ann. Geophys. 3:615-628.

Verdonck, O. 1984. Reviewing and evaluation of new materials used as substrates. Acta Hort. 150:467-473.

Vidhana Arachchi, L.P. and L.L.W. Somasiri. 1997. Use of coir dust on the productivity of coconut on sandy soils. Cocos 12:54-71.

Von Post, L. 1937. The geographical survey of Irish bogs. Irish Natl. J. 6:210-227.

Wallach, R., F.F. da Silva, and Y. Chen. 1992a. Hydraulic characteristics of tuff (scoria) used as a container medium. J. Amer. Soc. Hort. Sci. 117:415-421.

Wallach, R., F.F. da Silva, and Y. Chen. 1992b. Unsaturated hydraulic characteristics of composted agricultural wastes, tuff, and their mixtures. Soil Sci. 153:434-441. 